Proc. Indian Acad. Sci. (Earth Planet. Sci.), Vol. 103, No. 1, March 1994, pp. 37-46.

C. Printed in India.

\title{
Structural set up in northern part of Kumaun Himalaya
}

\author{
L S CHAMYAL and MANUDIP KAUR \\ Department of Geology, The Maharaja Sayajirao University of Baroda, Baroda 390002, \\ India
}

MS received 2 November 1993; revised 22 February 1994

\begin{abstract}
The Main Central Thrust (MCT) and the Main Boundary Thrust (MBT) are the two major thrusts in Kumaun, the MCT forming the boundary between highly sheared, deformed and mylonitized rocks of the Great Himalayan Central Crystallines and the Lesser Himalayan metasedimentaries. While in the Central Crystallines four-folding episodes are observed of which two are of the Precambrian age, the Lesser Himalayan rocks show only two phases of folding. MCT has its own distinctive structural history and the crystalline mass comprises an integral part of peninsular India.
\end{abstract}

Keywords. Structure; Central Crystallines; MCT; Kumaun Himalaya.

\section{Introduction}

The tectonic plane, separating the Lesser Himalaya from the Higher Himalaya and known as the Main Central Thrust (MCT) has thrown up the Precambrian basement rocks. The rocks of the Higher Himalaya forming a part of the 'Central Crystallines' of Heim and Gansser (1939) are sandwiched between the Trans Himadri Fault (THF) in the north and MCT in the south (Valdiya 1988). Between these two tectonic boundaries occur varied assemblages of schistose and gneissose rocks. These form basement for the sediments of Tethys Himalaya in the north and to the south occur feebly metamorphosed quartzites, slates, phyllites and limestones (Chamyal 1991). However, according to Valdiya $(1977,1988,1989,1991,1993)$ the real MCT occurs at a higher stratigraphic level than that cited by all other workers and has designated this delimiting boundary as Vaikrita Thrust.

On a regional scale considerable structural data has been generated on the MCT and the overlying and underlying rocks and only the broad details of the structural set up of the area are available (Misra and Bhattacharya 1976; Valdiya 1978, 1979, 1980, 1987, 1988; Thakur 1981; Chamyal 1987; Roy and Valdiya 1988; Chamyal and Vashi 1989). The paper presents a broad synthesis of the work done by the authors in the valleys of Pindar, Sarju, Ramganga and Goriganga of Higher Kumaun Himalaya.

\section{Lithostratigraphy}

In the northern Kumaun, the Lesser Himalayan metasedimentaries are tectonically overlain by a great thickness of metamorphics forming the 'Central Crystalline' 


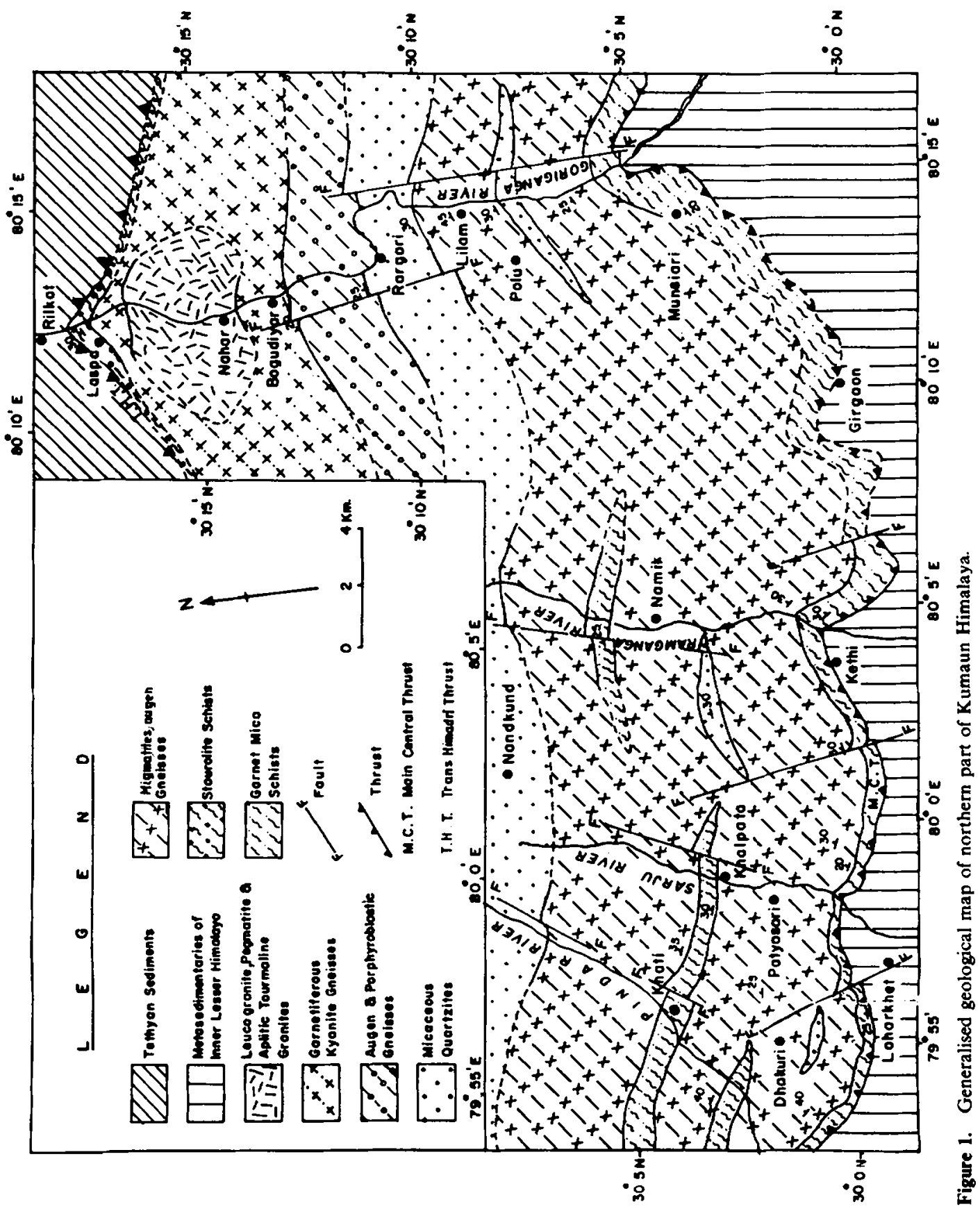


Tabte 1. Structural sequence of the crystalline rocks in northern Higher Kumaun Himalaya.

\begin{tabular}{|c|c|c|}
\hline Pindar and Sarju valley & Ramganga valley & Goriganga valley \\
\hline $\begin{array}{l}\text { Psammitic gneisses with } \\
\text { pegmatitic and aplitic granites. }\end{array}$ & & Trans Himadri Thrust \\
\hline Sericitic quartzites. & & Staurolite schists. \\
\hline Kyanite schists and gneisses. & & $\begin{array}{l}\text { Leucogranite, pegmatitic and } \\
\text { aplitic tourmaline granites, } \\
\text { gametiferous kyanite gneisses. }\end{array}$ \\
\hline \multirow{2}{*}{$\begin{array}{l}\text { Gneissic granites, augen gneisses } \\
\text { with micaceous quartzites. }\end{array}$} & Quartzites and calc silicate. & Calc silicatefels. \\
\hline & & Micaceous quartzites. \\
\hline $\begin{array}{l}\text { Augen and porphyroblastic } \\
\text { gneisses. }\end{array}$ & Kyanite gneiss. & Gamert kyanite gneiss. \\
\hline Schistose biotite gneiss. & Sericite and staurolite schists. & $\begin{array}{l}\text { Augen and porphyroblastic } \\
\text { gneisses with sericite, staurolite } \\
\text { schists. }\end{array}$ \\
\hline $\begin{array}{l}\text { Augen and migmatite and } \\
\text { gneissose siliceous feldspathic } \\
\text { mica schists. }\end{array}$ & $\begin{array}{l}\text { Migmatites and porphyroblastic } \\
\text { gneisses. }\end{array}$ & $\begin{array}{l}\text { Augen and migmatites with } \\
\text { micaceous quartzites and } \\
\text { staurolite schists. }\end{array}$ \\
\hline $\begin{array}{l}\text { Garnetiferous mica schists, chlo- } \\
\text { rite and sericite schists with } \\
\text { interbedded amphibolite lenses. }\end{array}$ & $\begin{array}{l}\text { Garnet mica schists, chlorite and } \\
\text { sericite schists with amphibolite } \\
\text { lenses. }\end{array}$ & $\begin{array}{l}\text { Garnetiferous mica schists, chlo- } \\
\text { rite and sericite schists. }\end{array}$ \\
\hline Main Central Thrust & Main Central Thrust & Main Central Thrust \\
\hline $\begin{array}{l}\text { Loharkhet quartzites, } \\
\text { Saling sjates, } \\
\text { Deoban carbonates }\end{array}$ & $\begin{array}{l}\text { Hokara quartzites, } \\
\text { Deoban carbonates }\end{array}$ & $\begin{array}{l}\text { Girgaon quartzites, } \\
\text { Deoban carbonates. }\end{array}$ \\
\hline
\end{tabular}

(figure 1). Various kinds of granitoids and schists form the dominant rock types, besides lenses of micaceous quartzites, calcsilicate rocks and amphibolites. The MCT zone is characterised by the presence of phyllonites on supra thrust and the sheared quartzites on infra thrust side. Though it is very difficult to precisely demarcate the various lithological types, a broad sequence of rocks seen in the valleys of Pindar, Sarju, Ramganga and Goriganga is given in table 1.

\section{Structure}

The generalized geological map, structural trend map of the area, geological cross section of the MCT zone and across Kumaun (figures 1, 2, 3A, B, C and 4) provide insight into the structure of Kumaun Higher Himalaya. The rocks of the Central Crystallines have been subjected to tremendous compression as evident from tight folds and polyphase deformation. There exists marked difference in the structural 


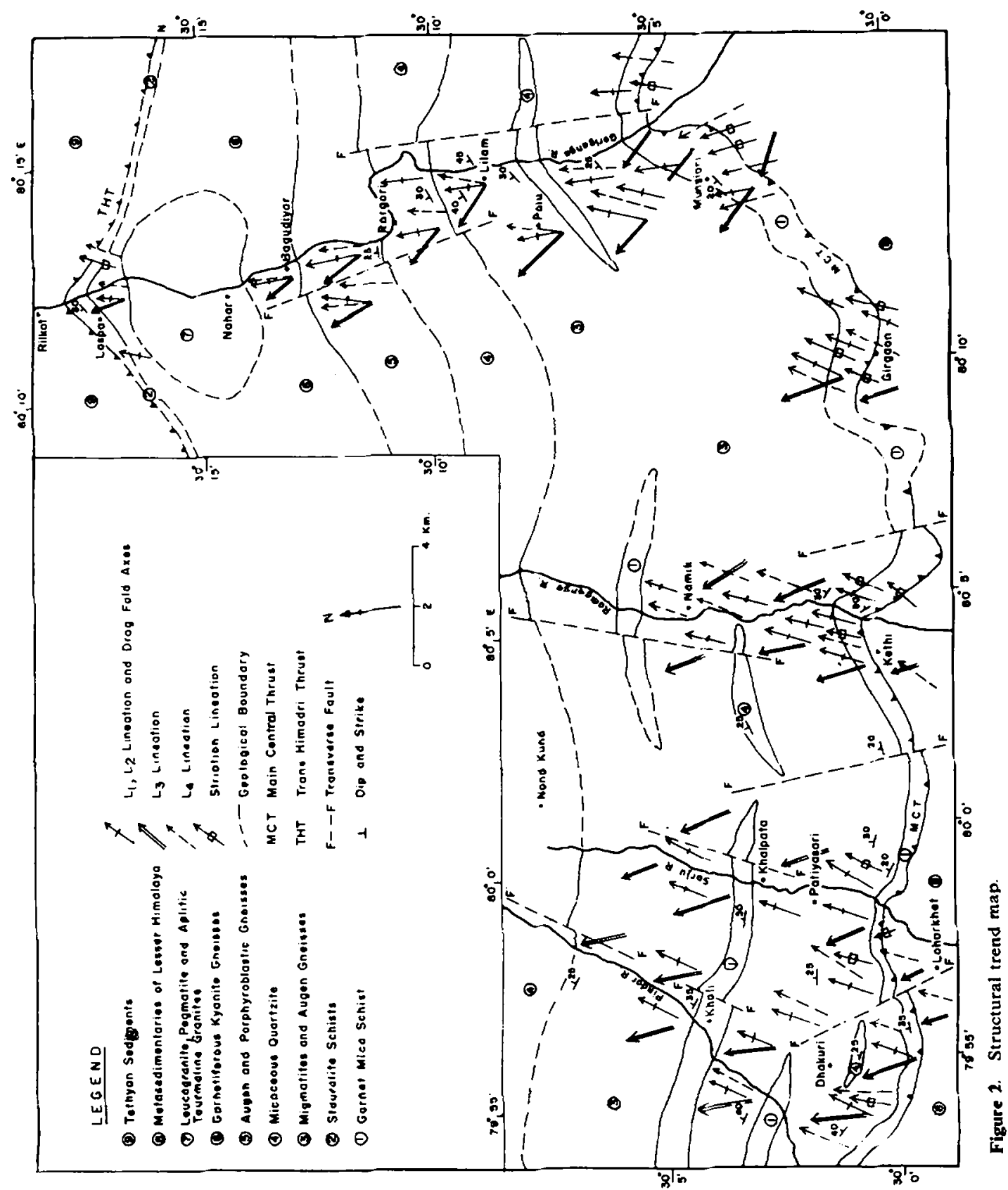



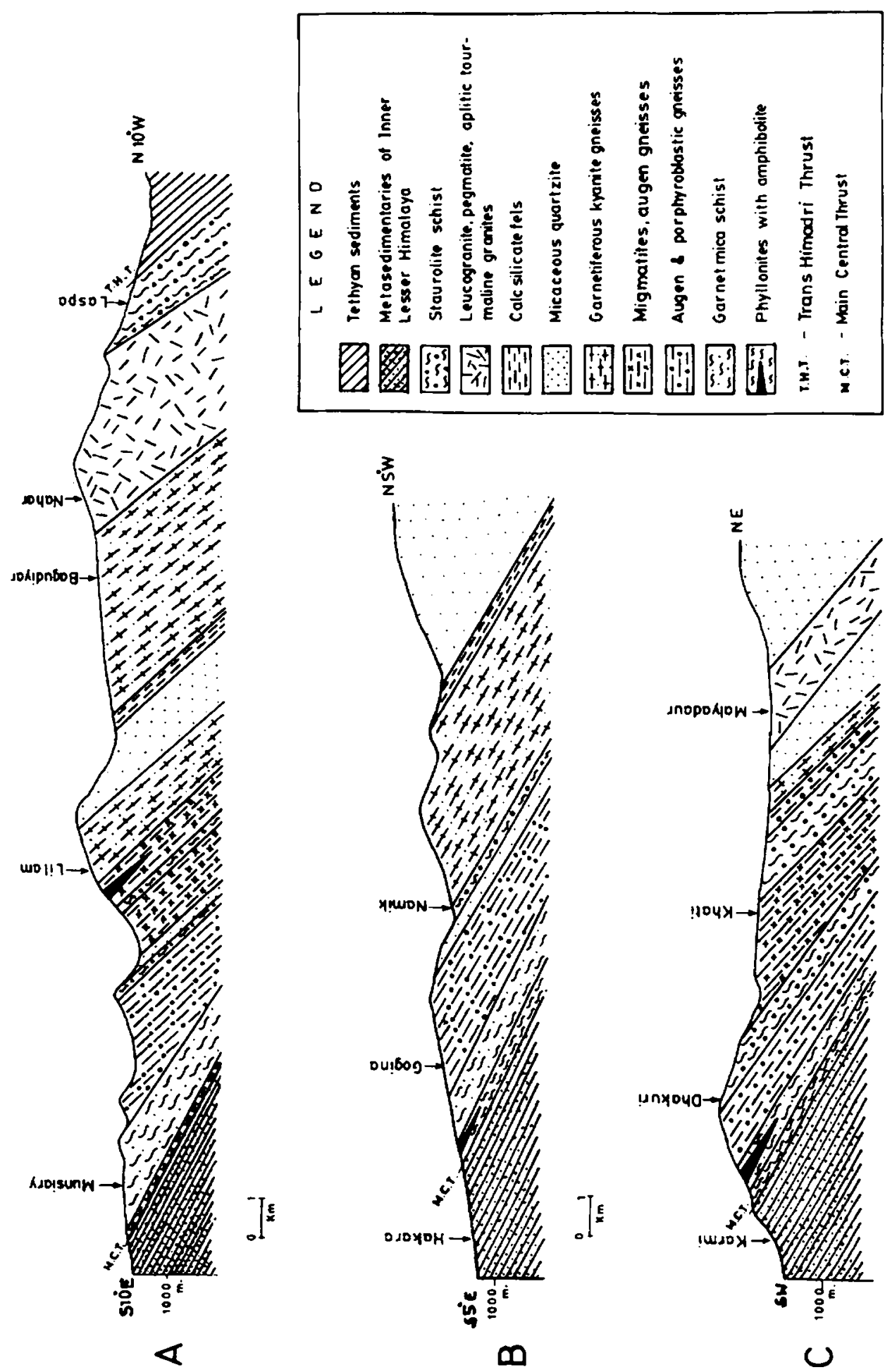

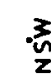

$\frac{3}{2}$

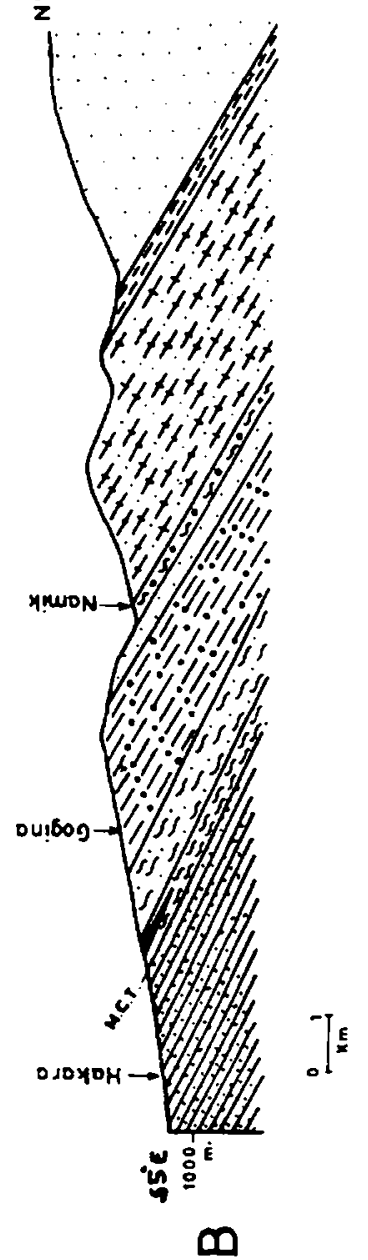

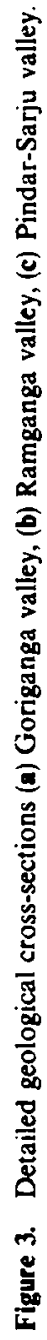

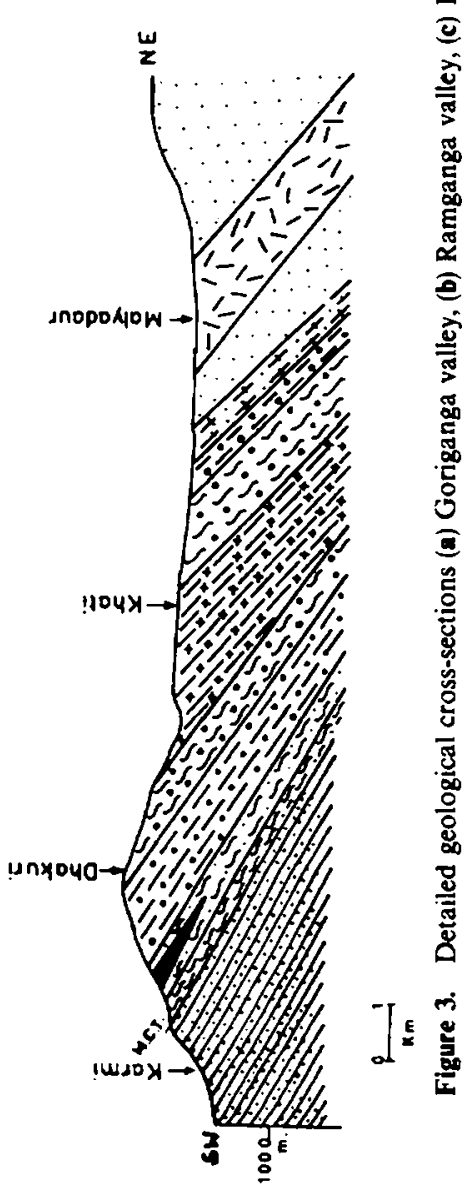

$\circlearrowleft$ 


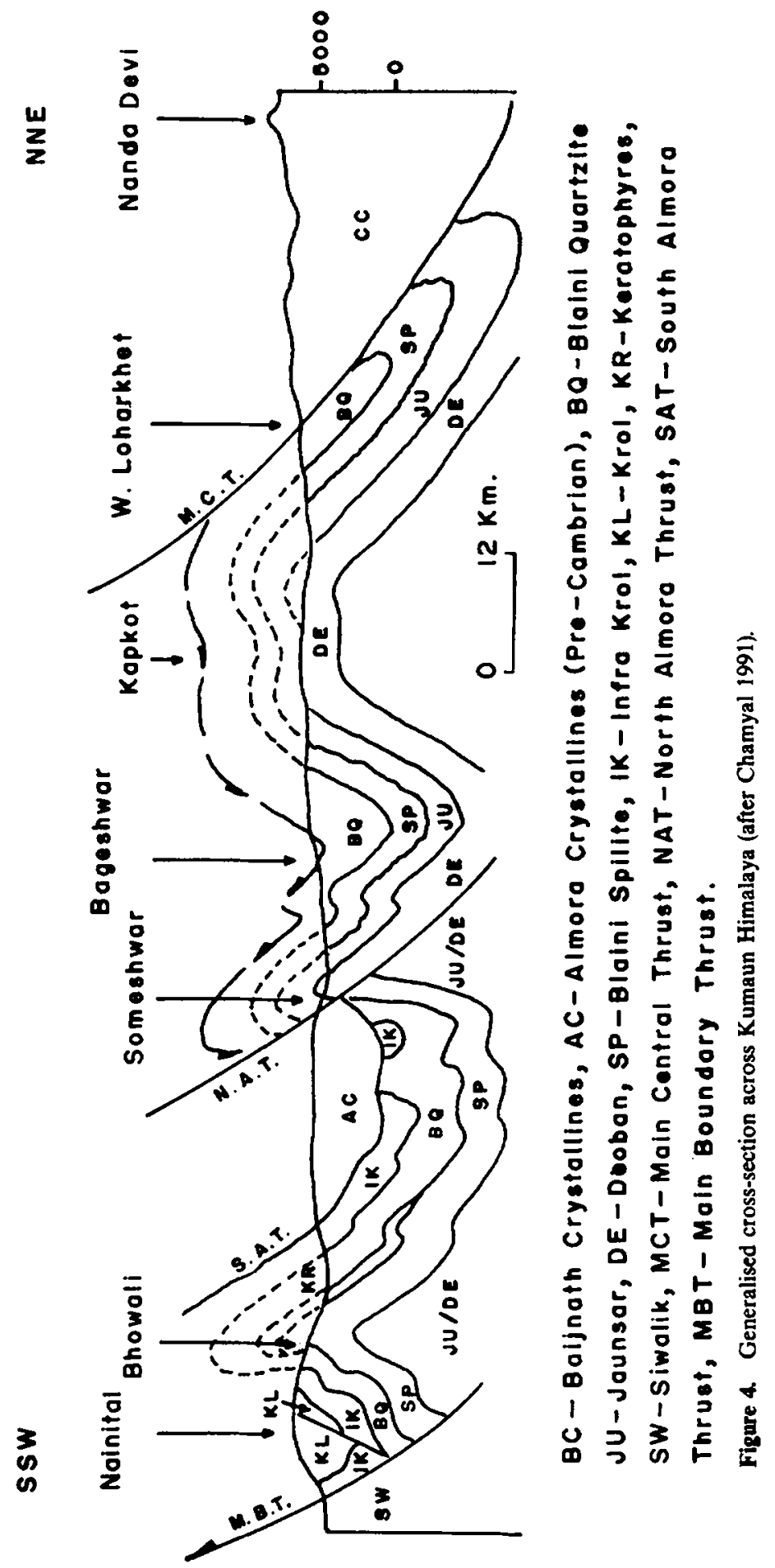


characteristics of the rocks on the two sides of the MCT. The fold history of the northern part of Kumaun Himalaya can be summarised as follows:

\begin{tabular}{lllll}
\hline Event & Nature & \multicolumn{2}{c}{$\begin{array}{r}\text { Pindar/Sarju/Ramganga } \\
\text { Goriganga valleys }\end{array}$} & Trend \\
\cline { 3 - 4 } & & $\begin{array}{l}\text { Lesser } \\
\text { Central } \\
\text { Crystallines } \\
\text { Himalayan } \\
\text { rocks }\end{array}$ & \\
\hline$F_{1}$ & $\begin{array}{l}\text { Isoclinal/ } \\
\text { Reclined }\end{array}$ & Present & Absent & NNE-NE/ \\
$F_{2}$ & $\begin{array}{l}\text { Isoclinal/ } \\
\text { Reclined }\end{array}$ & Present & Absent & NSW-SW \\
$F_{3}$ & $\begin{array}{l}\text { Synformal } \\
\text { folding }\end{array}$ & Present & Present & SSW-SW \\
$F_{4}$ & $\begin{array}{l}\text { Flexural } \\
\text { folding }\end{array}$ & Present & Present & NE-SW \\
& & & & \\
\hline
\end{tabular}

The first two foldings $\left(F_{1}\right.$ and $\left.F_{2}\right)$ are recorded only in the Central Crystallines and are of Precambrian age (Merh 1984; Chamyal and Vashi 1989). These are co-axial, having identical geometry with variable plunges towards NNE/SSW and are represented by tight isoclinal/reclined folds. The main schistosity of the rocks is generally seen to represent axial plane cleavage of $F_{2}$, though relicts of the earliest axial plane foliation related to $F_{1}$ are abundantly recorded. Most of the gneissic bands occurring within the schists as well as layers of quartzites ideally show $F_{1}$ and $F_{2}$ folds at mesoscopic as well as microscopic scales. The gneissic bands are involved in $F_{1}$ and $F_{2}$ and it is likely that they constitute $F_{1}$ fold cores refolded on $F_{2}$. The hinge portions of the mesoscopic folds are generally thick and the limbs are thin. The rootless and tight folds of $F_{1}$ and $F_{2}$ generation are more intense in the thrust zone. However, the two tectonic units (Vaikrita and Munsiari) of Valdiya (1977) according to Roy and Valdiya (1988) show different structural patterns.

A thrust movement along the pre-existing lineament (MCT) pushed the crystallines over the Lesser Himalayan rocks (Chamyal and Vashi 1989). The MCT is characterised by a narrow zone striking E-W to NW-SE dipping due $\mathrm{N}$ to NE. The movement along this thrust has not only sheared the rocks but has also given rise to a new set of folds (related to the drag effect) superimposed over the Precambrian deformation. The drag folds also show a NNE to NE axes, and it appears that the major movement along the MCT was from NW. The axes of the drag folds mark the thrust related linear structure $\left(L_{T}\right)$ while the phyllonitic cleavage represents the planar structure. Besides the drag folds also observed, rootless and tight folds in the vicinity of the thrust with their plunge in the same direction NNE to NE or SSW to SW. It is just a coincidence or identical nature of movement directions that $F_{1}$ and $F_{2}$ folds and the thrust related drag folds show similar trends. The ' $a$ ' lineation (striation) which is the effect of flexural slip during a later folding $\left(F_{3}\right)$ also show a northeasterly trend.

The $F_{3}$ folds trend $\mathrm{NW} / \mathrm{SE}$ and are open in nature, related to this are various 
mesoscopic synformal nappes with asymmetrical and symmetrical parasitic folds. This folding is found in both the tectonic units and is almost right angles to $F_{1}$ and $F_{2}$. The planar structure related to $F_{3}$ include the axial plane cleavage $S_{3}$ trending NW/SE dipping moderately $\left(20-30^{\circ}\right)$ towards $N W$. The $F_{4}$ is also common in both the units, marking the last fold event, has imparted waviness to the regional foliation trends. The folds are open to chevron trending NNE-NE/SSW-SW. The planar and linear elements related to $F_{4}$ include the axial plane cleavage $\left(S_{4}\right)$ trending NE-SW and crenulation axes $\left(L_{4}\right)$ trending NE/NNE-SW/SSW with deviations towards N-S direction.

Roy and Valdiya (1988) while describing the tectonometamorphic evolution of the Kumaun Himalaya classified the small scale structures into two types - (i) folds parallel to lineation and (ii) folds at high angles to lineation. According to them $F_{1}$ and $F_{2}$ folds (and their subtypes) have formed under different tectonic conditions and the terms $F_{1}$ and $F_{2}$ do not imply the chronological order of their formation, but are descriptive terms indicating the orientation of the axes and axial planes of the folds in relation to the direction of tectonic transport. However Chamyal and Vashi (1989) do not think so and have assigned Precambrian age to $F_{1}$ and $F_{2}$ and Himalayan to Late-Himalayan ages to $F_{3}$ and $F_{4}$.

The microstructural studies of the metasedimentaries lying below the MCT show that the carbonates have developed only a poor cleavage, the intensity of which decreases southward. Fractures and veins are abundant and the carbonates are recrystallized with grain sizes varying from $1 \mathrm{~mm}$ to $10 \mathrm{~mm}$. The overlying slates and phyllites are characterised by a penetrative cleavage. Later kinks and crenulation folds are very intense and well developed. The deformation intensity is much more in the quartzites lying immediately below the MCT. The quartz grains exhibit undulose extinction, overgrowths, sutured grain boundaries and several overprinting schistosities are observed in the chlorite schists intercalated with quartzites. All these characteristics indicate that the increasing amount of internal deformation northward is due to the nearness of MCT.

\section{Discussion}

The existence of the MCT in the northern part of Kumaun Himalaya has been quite vital in working out the overall tectonic framework. The rocks of Higher Himalaya have atleast undergone effects of deformation and metamorphism of two generationsPrecambrian and Tertiary. The rocks overlying and underlying the MCT show metamorphic and structural features quite distinct from each other. The Central Crystallines comprise a part of the Precambrian Indian Shield (Gansser 1964; Naqvi et al 1974; Crawford 1974; Chamyal and Vashi 1989). According to Chamyal et al (1984) the MCT is a pre-Himalayan tectonic feature that developed during the waning phase of the Hercynian orogeny on account of crustal stretching and rifting, the mechanism related to process of abduction along the northern flank of the subducted mid-oceanic ridges, the spreading centre of the proto-Tethys ocean. The Central Crystallines comprise a tectonic flake demarcated by the MCT. It thus neither marks a simple overthrust nor does it represent a major plate boundary but it is an intracrustal boundary thrust (Valdiya 1981).

The tectonic weak zone that developed in pre-Himalayan times was obviously 
reactivated during the initial stages of the Himalayan orogeny (Chamyal et al 1984), pushing the older crystallines over the Lesser Himalayan rocks. The drag fold axes related to this early Himalayan thrusting point to a strike-slip movement along the pre-existing fracture in a NW-SE direction. The lateral displacement was caused due to the NE movement of the Indian plate whose stress was trending WNW-ESE and right laterally directed towards east (Sychanthavong and Shah 1980). The MCT thus could very well be compared to a right lateral transcurrent fault.

Of the four folding episodes the most obvious event expressed by the rocks of Higher Himalaya has been $F_{2}$ which produced wide spread cleavage. According to Chamyal (1987) the first deformation $\left(F_{1}\right)$ produced Quartz-oligoclase-muscovitebiotite-garnet-staurolite and metamorphosed the pelitic rocks to garnet (staurolite) mica schists. Karanth (1985) has also observed similar features in the rocks of Almora nappe. The next deformational event $\left(F_{2}\right)$ recrystallized the rocks, to produce a crenulation cleavage $\left(S_{2}\right)$. The metamorphism reached upto Sillimanite grade of upper amphibolite facies.

During the next major deformational episode $\left(F_{3}\right)$ the crystalline tlirust sheet was folded into numerous synforms, the relicts of which are seen as crystalline nappes in the Lesser Himalaya. A strong striation lineation of the nature of slickensides and mineral stretching developed along the thrust plane on account of intense flexural slip movement. All over the northern part of Kumaun Himalaya the last deformational episode is characterised by transverse faults. The transverse faults trending NNW-SSE or NNE-SSW show considerable crushing, shearing, displacement in the MCT and rock formations, offsetting of drainage pattern etc. These faults have right laterally displaced MCT by as much as 50 to $100 \mathrm{~m}$ and has dissected the Lesser Himalayan rocks as well.

It is beyond doubt that the Central Crystallines have over-ridden the Lesser Himalayan rocks in northern Kumaun along MCT. Gansser (1964) stated that the crystallines form the basement for the Tethyan sequence. The present authors however feel that the crystalline mass comprise an integral part of peninsular India as is also believed by many others. Having been affected by pre-Himalayan orogenies the frontal portion of the Indian shield was shattered and MCT geofracture was developed, which was reactivated during the Himalayan orogeny. The crystalline block (upthrusted block) might have undergone drastic deformation and transformation at depth during this orogeny.

\section{Acknowledgements}

The authors are indebted to Prof. S S Merh for valuable guidance and encouragement. The second author (M K) is grateful to W.I.H.G. Dehradun for financial assistance.

\section{References}

Chamyal L S 1987 Some petrographic studies on the crystalline rocks of Dhakuri area in Kumaun Himalaya; J. Indian Acad. Geosci., Hyderabad 30 1-15

Chamyal L S 1991 Stratigraphy of lesser Himalayan rocks in Kumaun; Proc. Indian Acad. Sci. (Earth Planet. Sci.) 100 293-306 
Chamyal L S and Vashi N M 1989 Tectonic framework and structural characteristics of the crystalline rocks of Kumaun Himalaya; Current trends in geology (ed.) P S Saklani (New Delhi: Today \& Tomorrows Printers and publishers) 11 91-106

Chamyal L S, Vashi N M and Merh S S 1984 On the nature of the Main Central Thrust in Kumaun Himalaya; Proc. Fifth Indian Geol. Cong. (ed.) B Bhaskar Rao (Dept. of Earth Sciences, IIT, Bombay) pp. $77-84$

Crawford A R 1974 A greater Gondwanaland; Science 184 1175-1181

Gansser A 1964 Geology of the Himalayas (London: Interscience) p. 289

Heim A and Gansser A 1939 Central Himalaya: Geological observations of Swiss expedition 1936 (Reprinted Delhi Hind. Publ. Co.) p. 246

Karanth R V 1985 New Petrographic data on the metapelites of Almora Crystallines in Kumaun Himalaya; J. Geol. Sac. India $26435-452$

Merh S S 1984 A reinterpretation of the structural set up of Kumaun Himalaya; Proc. Fifth Indian Geol. Cong. (ed.) B Bhaskar Rao (Dept. of Earth Sciences, IIT, Bombay) pp. 57-64

Misra R C and Bhattacharya A R 1976 The Central Crystalline zone, northern Kumaun Himalaya; its lithostratigraphy, structure and tectonics with special reference to plate tectonics; Himalayan Geol. 6 133-154

Naqvi S M, Divakar Rao V and Hari Narain 1974 The protocontinental growth of the Indian shield and the antiquity of its rift valleys; Precambrian Res. $1345-398$

Roy A B and Valdiya K S 1988 Tectonometamorphic evolution of the Great Himalayan Thrust Sheets in Garhwal region, Kumaun Himalaya; J. Geol. Soc. India 32 106-124

Sychanthavong S P H and Shah A N 1980 Tectonic evolution and stress conditions in the development of the Kathmandu Nappe and Kathmandu Basin, Nepal Himalaya; Himalayan Geol. 10 304-325

Thakur V C 1981 An overview of thrust and nappes of Western Himalaya; Thrust and Nappe tectonics (eds.) N S Price and K McKlay (Geol. Soc. London) pp. 381-392

Valdiya K S 1977 Structural set-up of the Kumaun Lesser Himalaya; Himalaya Science de la Terre, Centre Nationale Richerche Science (Paris) 268 449-462

Valdiya K S 1978 Extension and analogous of the Chail Nappe in the Kumaun Himalaya; Indian J. Earth Sci. 5 1-19

Valdiya K S 1979 An outline of the structural set up of the Kumaun Himalaya; J. Geol. Soc. India 20 147-157

Valdiya K S 1980 The two intracrustal boundary thrusts of the Himalaya; Tectonophysics 66 323-348

Valdiya K S 1981 Tectonics of the Central sector of the Himalaya; Himalayan Geody. Evol. Sr. 387-110

Valdiya K S 1987 Trans-Himadri Thrust and domal upwarps immediately south of collision zone and tectonic implications; Curr. Sci. 56 200-209

Valdiya K S 1988 Tectonics and evolution of the central sector of the Himalaya; Philos. Trans. R. Soc. London 326 151-175

Valdiya K S 1989 Neotectonic implication of collision of Indian and Asian plates; Indian J. Geol. 61 1-13

Valdiya K S 1991 Quaternary tectonic history of northwest Himalaya; Curr. Sci. 61 664-668

Valdiya K S 1993 Uplift and geomorphic rejuvenation of the Himalaya in the Quaternary period; Curr. Sci. $64873-885$ 